\title{
Single-agent post-transplantation cyclo- phosphamide versus calcineurin-based graft-versus-host disease prophylaxis in matched related bone marrow transplantation
}

Ivan S. Moiseev ${ }^{1,2}$, Olga V. Pirogova ${ }^{1}$, Elena V. Babenko ${ }^{1}$, Tatyana L. Gindina ${ }^{1}$, Elena I. Darskaya ${ }^{1}$, Elena V. Morozova ${ }^{1,2}$, Sergey N. Bondarenko ${ }^{1}$, Boris V. Afanasyev ${ }^{1,2}$

${ }^{1}$ R. M. Gorbacheva Memorial Institute of Children Hematology, Oncology and Transplantation, Pavlov First Saint Petersburg State Medical University

${ }^{2}$ Chair of Hematology, Transfusiology and Transplantation, Pavlov First St. Petersburg State Medical University, St. Petersburg, Russian Federation

Dr. Ivan S. Moiseev, PhD, Deputy Director for Research, R.Gorbacheva Memorial Research of Children Hematology, Oncology and Transplantation, The First St. Petersburg State I. Pavlov Medical University, L.Tolstoy St. 6/8, 197022,

St. Petersburg, Russian Federation,

\section{Summary}

A number of studies were published demonstrating efficacy of single-agent graft-versus-host disease prophylaxis (GVHD) with post-transplantation cyclophosphamide (saPTCy) in matched related bone marrow transplantations (BMT), however no comparisons were published so far between saPTCy and conventional GVHD prophylaxis based on calcineurin inhibitors (CNIs). In this study, 78 patients grafted with bone marrow from matched related donor (MRD) with saPTCy GVHD prophylaxis were compared to 105 historical control patients also receiving bone marrow from MRD, but with tacrolimus/cyclosporine A and mycophenolate mofetil/methotrexate prophylaxis. Groups were comparable in pre-transplant characteristics of patients, except higher prevalence of salvage patients and acute lymphoblastic leukemia in CNIs cohort. PTCy was superior to CNIs in prevention of grade II-IV (HR $0.239,95 \%$ CI 0.099-0.58, $\mathrm{p}=0.002$ ) and grade III-IV acute GVHD (HR 0.192, 95\% CI 0.055-0.666, p=0.009), relapse
Phone: +7 (812) $3386259,+7$ (921) 7961951

Fax: +7 (812) 3386263

E-mail:moisiv@mail.ru
(HR 0.519, 95\% CI 0.297-0.893, $\mathrm{p}=0.023$ ). No difference was observed for moderate and severe chronic GVHD (HR $0.898,95 \%$ CI 0.477-1.69, p=0.74) and non-relapse mortality (HR 0.384, 95\% CI 0.089-1.437, p=0.1768). Patients after saPTCy had improved overall survival (HR 0.489, 95\% CI 0.261-0.917, $\mathrm{p}=0.03$ ), event-free-survival (HR 0.571, 95\% CI $0.334-0.976, \mathrm{p}=0.04$ ) and GVHD-relapse-free survival (HR 0.493, 95\% CI 0.309-0.786, $\mathrm{p}=0.003$ ). The toxicity of BMT was generally comparable, except lower incidence of nephrotoxicity (33\% vs 43\%, p=0.008) after PTCy, but with higher incidence of grade 3-4 mucositis in this group (41\% vs $34 \%, \mathrm{p}=0.02$ ). Despite limitations of single-center retrospective design, this study demonstrated superiority of saPTCy vs CNI-based prophylaxis, but these results should be confirmed in prospective randomized trials.

\section{Keywords}

Bone marrow transplantation, graft-versus-host disease, post-transplantation cyclophosphamide, prophylaxis. 


\section{Introduction}

Graft-versus-host disease (GVHD) prophylaxis based on calcineurin inhibitors (CNI), namely cyclosporin A and tacrolimus, was developed in 1980s by Donald Thomas group [1] and is still the standard of care in the majority of European centers [2]. Although tacrolimus and cyclosporin A have some differences in the efficacy after unrelated hematopoietic stem cell transplantation (HSCT), there are no significant differences between these two agents for matched related grafts in the majority of studies [3,4]. This type of prophylaxis results in grade II-IV acute GVHD and chronic GVHD in about $20-40 \%$ of patients undergoing HSCT from matched related donors (MRD) [5-7].

A recent study by Luznik et al. demonstrated that post-transplant cyclophosphamide (PTCy) could be used as single-agent GVHD prophylaxis for matched bone marrow grafts with relatively low incidence of acute and chronic GVHD [8]. This finding was subsequently confirmed in a multicenter study [9]. The single-agent PTCy regimen is associated with low immunosuppression burden and relatively fast immunologic recovery, so it is anticipated to reduce the rate of infectious complications and potentiate graft-versus-leukemia (GVL) effect $[10,11]$. However, no studies were published with direct comparison of the prophylaxis with CNIs and PTCy as the single agent. This retrospective study compares patients transplanted for malignant diseases with these two types of GVHD prophylaxis.

\section{Patients and methods}

\section{Patients and transplantation procedures}

183 patients transplanted in 2006-2016 at the First St.Petersburg State I. Pavlov Medical University were enrolled in the study. Only first allogeneic transplantations were included. All patients received 10/10 HLA-matched bone marrow graft from related donor. The Ethical Committee of Pavlov First St. Petersburg State Medical University approved the usage of PTCy as a single-agent for GVHD prophylaxis. All patients signed informed consent for the use of their medical data to research purposes. 78 subjects received PTCy, and 105 were administered either cyclosporine A or tacrolimus combined with a second immunosuppressive agent. $49 \%$ of patients had acute myeloid leukemia; $31 \%$, acute lymphoblastic leukemia (ALL); 8\%, chronic myeloid leukemia; 3\%, myelodysplastic syndrome, and $8 \%$, malignant lymphomas. $27 \%$ of patients underwent salvage transplantation, defined as acute leukemia without hematologic remission, chronic myeloid leukemia in blast crisis and lymphomas in less than partial remission status. Comparative clinical characteristics of the two groups are presented in Table 1. PTCy group comprised less ALL patients, less salvage patients and a significantly later year of transplant. The other characteristics were comparable. Median follow-up in the control group was 50 months (range 8 to 111); in the PTCy group, 24 months (range 5 to 41 ).

Table 1. Characteristics of patients and transplantation conditions

\begin{tabular}{|l|l|l|l|}
\hline Parameter/groups & CNI-based prophylaxis & Single-agent PTCy & p-value \\
\hline No. of patients & 105 & 78 & \\
\hline Gender, \% M/F & $59 \% / 41 \%$ & $55 \% / 45 \%$ & 0.60 \\
\hline Age, years, median (range) & $31(18-68)$ & $34(18-59)$ & 0.89 \\
\hline Diagnosis & & & \\
AML & $49 \%$ & $48 \%$ & 0.03 \\
ALL & $34 \%$ & $26 \%$ & \\
CML & $4 \%$ & $14 \%$ & \\
Lymphomas & $8 \%$ & $11 \%$ & \\
MDS & $5 \%$ & $1 \%$ & 0.0008 \\
\hline Salvage group & $36 \%$ & $14 \%$ & 1.0 \\
\hline Donor type & $100 \%$ & $100 \%$ & \\
MRD & & & 1.0 \\
\hline Graft source & $86(43 \%)$ & $57(100 \%)$ & \\
BM & & & 0.58 \\
\hline Conditioning & $33 \%$ & $29 \%$ & \\
MAC & $67 \%$ & $71 \%$ & \\
RIC & $31 \%$ & - & \\
\hline Cycloporin A & $69 \%$ & - & \\
Tacrolimus & $50 \%$ & $3.1 \pm 1.2$ & \\
\hline Methotrexate & $50 \%$ & $2015(2014-2016)$ & $<.001$ \\
\hline MMF & $3.1 \pm 1.9$ & & \\
\hline CD34+/kg & $2011(2006-2016)$ & & \\
\hline Year of transplant, median (range) & & & \\
\hline
\end{tabular}




\section{Transplantation procedures}

Myeloablative conditioning (MAC) was performed with oral busulfan at a dose of $16 \mathrm{mg} / \mathrm{kg}$ and cyclophosphamide (100-120 mg/kg). Reduced intensity conditioning (RIC) was performed with fludarabine $(180 \mathrm{mg} / \mathrm{m} 2)$, and busulfan $(8 \mathrm{mg} / \mathrm{kg})$. Patients were assigned to RIC if they were 40 years or older, had HSCT-specific comorbidity index (HCT$\mathrm{CI}) \geq 2$, grade $>3$ hepatic toxicity during induction therapy, or uncontrolled infection at the start of conditioning.

GVHD prophylaxis in the PTCy group consisted of single-agent cyclophosphamide $(50 \mathrm{mg} / \mathrm{kg})$ administered at days $+3,+4$. Mesna $(50 \mathrm{mg} / \mathrm{kg} /$ day $)$ was administered during the days of PTCy infusion. Glucocorticoid administration was prohibited from day -5 until day +5 , except of cases with anaphylaxia and severe respiratory failure. In the groups with conventional prophylaxis, the patients received either tacrolimus with target concentrations of 5-15 ng/ml, or cyclosporine A, starting from the day -1 , with target concentrations of 150-350 ng/ml. The second agent in the prophylaxis regimen was methotrexate administered as a short course $(10-15 \mathrm{mg} / \mathrm{m} 2)$ at days $+1,+3,+6$, or mycophenolate mofetil (MMF) $30 \mathrm{mg} / \mathrm{kg}$ from day -1 to day +30 .

Supportive care included omeprasole $40 \mathrm{mg} /$ day, acyclovir $600 \mathrm{mg} /$ day, trimetoprim/sulfamethaxazole $960 \mathrm{mg} / \mathrm{day}$, allopurinol and unfractionated heparin (100 IU/kg/day) starting day -7. In patients without previous history of invasive fungal infection, prophylaxis was done with fluconazole (400 mg/day) starting on day 0, in patients with history or evidence of invasive aspergillosis, with voriconazole (400 mg/day) starting on day 0. Premedication before graft transfusion in the PTCy group was performed with metamesole $2 \mathrm{~g}$ and diphenhydramine $20 \mathrm{mg}$ and steroids $1 \mathrm{mg} / \mathrm{kg}$ were added in the conventional prophylaxis group.

\section{Clinical definitions}

Time to disease relapse, acute GVHD (GVHD), moderate to severe chronic GVHD (cGVHD), non-relapse mortality (NRM), overall survival (OS), event-free survival (EFS), and GVHD-relapse free survival (GRFS) were defined as the time from transplantation to the event. All these parameters were calculated for the two-year interval. Incidence of aGVHD was calculated at 125 days after HSCT, and the time frame for the other outcomes was three years. Events for EFS were relapse or death. Events for GRFS were either death, relapse, grade III-IV acute GVHD or systemic therapy-requiring chronic GVHD. The Consensus Conference criteria and NIH criteria were used for aGVHD and cGVHD grading, respectively $[12,13]$. Primary graft failure was defined as a complete absence of donor chimerism in bone marrow biopsy by day +40 . Time to engraftment was calculated as a time period from HSCT to unsupported neutrophil count of $>500 / \mu \mathrm{l}$ and white blood cell count $>1000 / \mu$ for 3 consecutive days. Toxicity was assessed with CTCAE ver. 4.03. Sepsis in the study was defined as systemic inflammatory reaction with microbiologically confirmed bacteremia. The multivariate correction was performed with Hematopoietic Cell Transplantation-specific Comorbidity Index (HCT-CI) [14] and disease risk index (DRI) by Armand et al. [15].

\section{Statistical Analysis}

Comparison of groups was performed by Chi-square test. The survival distributions for OS, EFS, GRFS were calculated using Kaplan-Meier methodology. The comparisons were made using the log-rank test. Cumulative incidence analysis with competing risks for aGVHD, cGVHD, relapse incidence and NRM was performed using Gray test. Relapse and NRM were accounted as competing risks. Early discontinuation of immunosuppression due to relapse or minimal residual disease was considered a competing risk for aGVHD. Donor lymphocyte infusion was considered a competing risk for cGVHD. Multivariate analysis was done using proportional hazard regression. Fine and Grey regression was used for the multivariate analysis of cumulative incidences [16]. Factors used for multivariate correction had at least $\mathrm{p}=0.15$ significance in the univariate analysis. Heterogeneities between the hazard ratios in the subgroup analysis were tested for significance using the Cochran's Q test, with df degrees of freedom. Incidence and severity of complications was compared using Mann-Whitney test. Analyses were conducted in SAS 9.3 (SAS Institute, Inc.).

\section{Results}

\section{Engraftment and graft-versus-host disease}

Incidence of primary graft failure was not different between groups ( 1.1 vs $1.6 \%, \mathrm{p}=0.42$ ). Nonetheless, engraftment in the PTCy group was slower when assessed by neutrophil count (19 vs 24 days, $\mathrm{p}<0.001)$ and platelet count (17 vs 23 days, $\mathrm{p}=0.005)$. Acute GVHD grade II-IV was significantly less frequent in the PTCy group ( $8 \%$ vs $27 \%$, p $=0.0021$, multivariate HR $0.239,95 \%$ CI $0.099-0.58)$. The superiority of PTCy was also observed for grade III-IV acute GVHD (4\% vs $15 \%, \mathrm{p}=0.0040$, multivariate HR 0.192 , 95\% CI 0.055 0.666) (Fig. 1). Incidence of grade I acute GVHD was not different ( $18 \%$ vs $13 \%$, p=0.39) in the PTCy and conventional prophylaxis groups, respectively.

Moderate and severe chronic GVHD was not different between PTCy and CNIs groups (26\% vs 30\%, p=0.938, multivariate HR 0.898, 95\% CI 0.477-1.69). Incidence of mild chronic GVHD was also not different ( $9 \%$ vs $10 \%$, p $=0.60$ ).

\section{Mortality, relapses and survival outcomes}

NRM was lower in the PTCy group in the univariate analysis ( $8 \%$ vs $22 \%, p=0.0195)$, although there was no difference when corrected for other variables (HR 0.384, 95\% CI 0.089$1.437, \mathrm{p}=0.1768)$. Relapse incidence was not different in the univariate analysis ( $40 \%$ vs $49 \%, \mathrm{p}=0.0896$ ) in the PTCy and CNIs groups, respectively. However, in the multivariate analysis the use of PTCy was associated with lower incidence of relapse (HR 0.519, 95\% CI 0.297-0.893, $\mathrm{p}=0.023$ ). These NRM and relapse incidence borderline improvements translated in superior OS ( $62 \%$ vs $41 \%, \mathrm{p}=0.0027$, multivariate HR 0.489 , 95\% CI $0.261-0.917$ ), EFS (52\% vs $31 \%$, $\mathrm{p}=0.0013$, multivariate HR $0.571,95 \%$ CI $0.334-0.976)$ and GVHD-relapse-free survival ( $30 \%$ vs $12 \%, \mathrm{p}=0.0006$, multivariate $\mathrm{HR}$ 0.493, 95\% CI 0.309-0.786) (Fig. 1). 


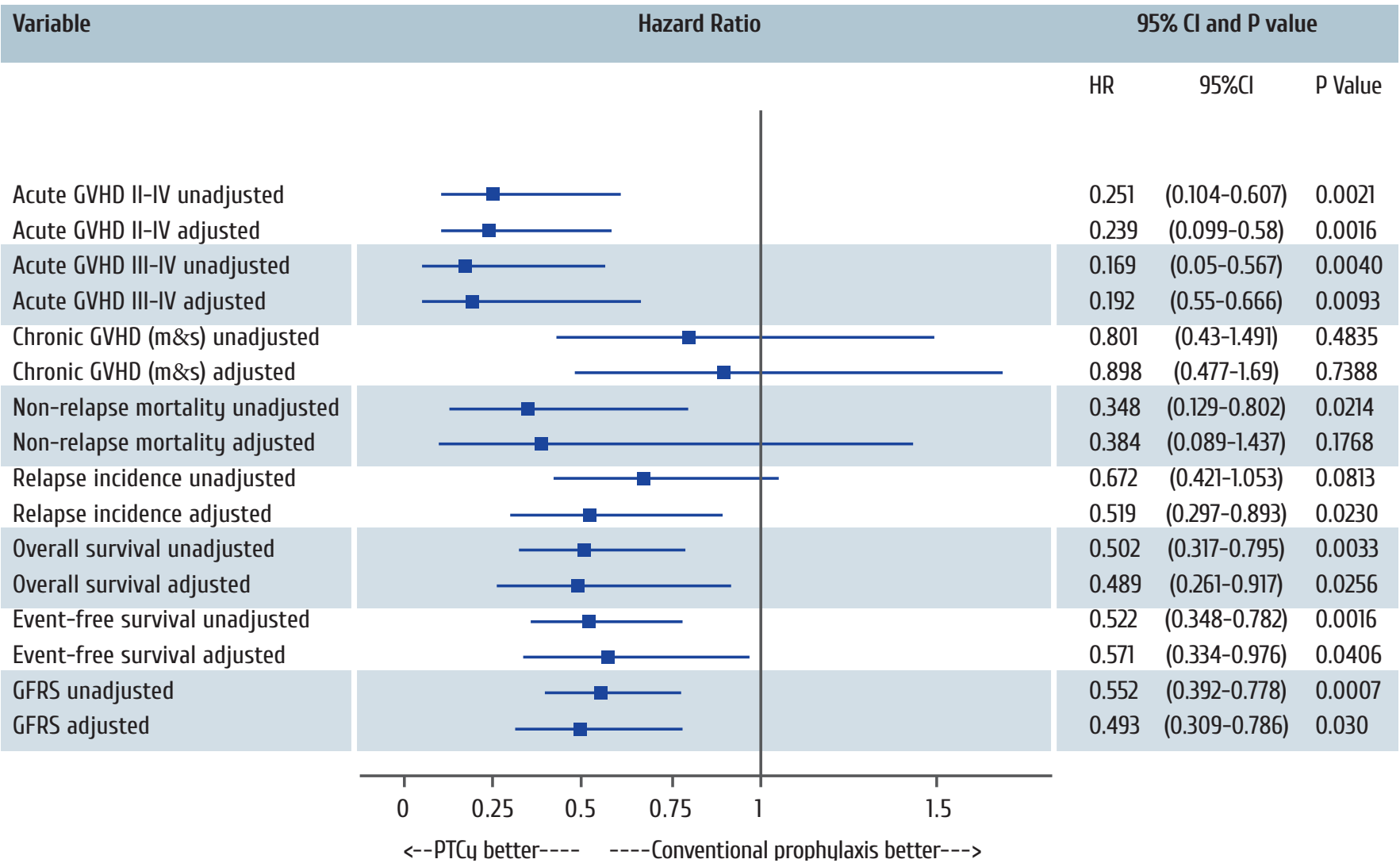

Figure 1. Univariate and multivariate analyses of transplantation outcomes

Unadjusted parameters represent results of univariate analysis; adjusted parameters represent results of multivariate analysis. In the multivariate analyses, co-variables for acute GVHD were as follows: intensity of the conditioning; age and female donor for male recipient. Co-variable for chronic moderate and severe (m\&s) GVHD was only previous acute GVHD; co-variables for NRM were intensity of the conditioning, salvage status, HCT-CI, occurrence of severe sepsis, female donor for male recipient, development of transplant-associated microangiopathy and year of transplant; co-variables for Relapse incidence were acute GVHD, chronic GVHD, intensity of the conditioning, salvage status, DRI, reactivation of cytomegalovirus, age and time to engraftment; co-variables for overall, event-free and GVHDrelapse-free survival were intensity of the conditioning, DRI, HCT-CI, CD34+ cells in the graft, severe sepsis, age and year of transplant.

The subgroup analysis of EFS demonstrated that significant benefit of PTCy prophylaxis was observed for both RIC (HR $0.57, \mathrm{p}=0.0175)$ and MAC (HR 0.38, $\mathrm{p}=0.0259)$, patients with high DRI (HR 0.584, $\mathrm{p}=0.0385$ ), patients younger than 40 years old (HR 0.497, $\mathrm{p}=0.0054)$, patients with acute leukemia $(H R=0.545, p=0.089)$, non-salvage group (HR 0.609, $\mathrm{p}=0.0493)$ and donor-recipient pairs other than female to male (HR 0.516, $\mathrm{p}=0.0077$ ). For the other subgroups, no significant differences were noted between PTCy and CNIbased prophylaxis, at least in the current study population ( $>0.05$ ), as seen in Fig. 2 .

\section{Complications of transplantation}

There was no difference in liver toxicity $(p=0.08)$, neuro- toxicity $(\mathrm{p}=0.11)$, incidence of hemorrhagic cystitis $(13 \%$ vs $14 \%, p=0.38)$, veno-occlusive disease $(\mathrm{p}=0.19)$, sepsis $(\mathrm{p}=0.06)$, severe sepsis $(\mathrm{p}=0.77)$, invasive mycosis $(\mathrm{p}=0.07)$, CMV reactivation $(\mathrm{p}=0.84)$ and "overall" transplant-assocciated microangiopathy (TAM) according to Cho et al criteria $(p=0.13)$ [17]. However, there was reduced incidence of nephrotoxicity in the PTCy group ( $33 \%$ vs $43 \%$, $\mathrm{p}=0.0079$ ), with no grade 3-4 cases observed in the PTCy group. A reduced incidence of mucositis was revealed after PTCy (78\% vs $88 \%, \mathrm{p}=0.0059)$, but grade 3 and 4 mucositis was more frequent in this group ( $41 \%$ vs $34 \%, \mathrm{p}=0.0163$ ). There was a borderline significant increase of sepsis incidence after PTCy ( $29 \%$ vs $17 \%, p=0.0566)$, but similar incidence of severe sepsis ( $6 \%$ vs $5 \%, \mathrm{p}=0.77)$.

\section{Discussion}

Despite previous reports of feasibility and safety of single-agent PTCy prophylaxis $[8,9]$ this is the first to our knowledge comparison of this regimen to conventional regimen consisting of CNI and second other agent, like MMF or methotrexate. It should be mentioned that, when compared to previous studies, the incidence of grade II-IV acute GVHD was lower in our cohort ( $8 \%$ vs $43-51 \%$ ). In the published trials, this could be explained by inclusion of patients with both related and unrelated grafts and by use of myeloablative therapy (MAC) in all the patients. In our study we included only related donors and majority of patients received RIC, which are the known factors that reduce GVHD incidence [18]. In this population of patients receiving predominantly RIC transplantation from related donor, a single-agent PTCy 


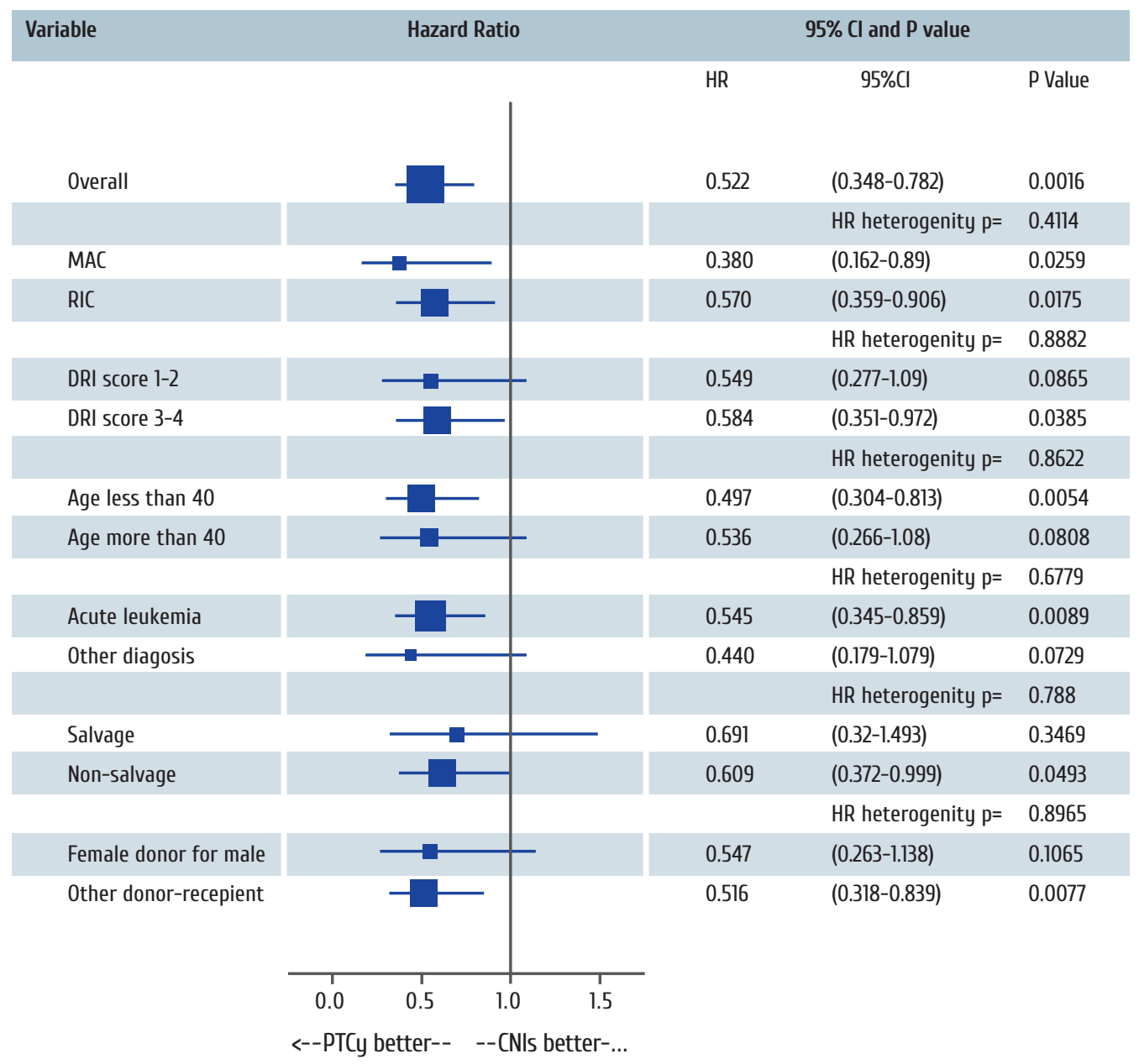

Figure 2. Subgroup analysis of event-free survival

Hazard ratio (HR) heterogeneity was calculated using Cochran's $Q$ test. The size of the marker represents the number of patients in the each subgroup.

was associated with lower acute, but not chronic GVHD incidence. All of the other outcomes in this cohort were generally comparable to the previous reports $[8,9]$ indicating the reproducibility of the results with single-agent PTCy.

We have observed a moderate superiority of PTCy, both in terms of NRM and relapse incidence, which, however, was translated into a significant benefit in OS, EFS and GFRS. The mechanisms underlying the improvement of results might include the reduced GVHD-related mortality, lower immunosuppression burden, preservation of certain T-cell antigen-specific subpopulations and faster development of graft-versus-leukemia (GVL) effect $[19,20]$. Interestingly, 30\% GRFS in the PTCy group indicate that one-third of the patients are cured without any further need for immunosuppression. However, the results of the study should be interpreted with caution because of its retrospective nature, inhomogeneous patient population, and differences in the time of transplant between the groups. The question whether single-agent PTCy is better than conventional prophylaxis should be addressed in a prospective clinical trial. The ongoing BMT CTN 1301 trial is addressing this issue, and the study completion is expected in 2021 [21].

The subgroup analysis revealed that the patients that benefit from PTCy are mostly young acute leukemia patients with high DRI. This could be explained by larger benefit of GVL in this population of patients [22]. Absence of differences in the other patient populations might be due to a small sample size in these subgroups, since all non-significant differences were observed in the smaller proportions of patients than did significant ones.

The analysis of clinical complications has shown a generally comparable safety profile between PTCy-based and CNIbased prophylaxis. A reduced nephrotoxicity is anticipated, since calcineurin inhibitors are well-known agents causing acute kidney damage [23]. Our group had also reported the reduced TAM incidence in unrelated grafts with PTCy [24], but the differences were not statistically significant in this patient cohort despite lower percentage (1\% vs 5\%). Larger studies are required to demonstrate that reduced acute GVHD incidence and absence of CNIs as well-known risk factors of TAM might diminish its occurence [25]. The alarming trend of higher sepsis incidence after PTCy might be a consequence of slower engraftment and longer neutropenia duration, but also, since PTCy group consisted of more recent transplantations, this might be due to improved sepsis diagnostics over time. The latter explanation might be more probable, because the incidence of bacteremia recently reported by other groups varies from 24 to $48 \%$ [26]. 


\section{Conclusion}

Despite the drawbacks of a single-center retrospective nature, our study in matched related bone marrow recipients has shown a reduced incidence of acute, but not chronic GVHD with single-agent PTCy compared to conventional GVHD prophylaxis. Moreover, the use of PTCy was associated with improved overall and event-free survival. These findings should be confirmed in multicenter prospective randomized trials.

\section{Financial Disclosure Statement}

The authors have nothing to disclaim.

\section{Acknowledgements and conflict of interests}

The authors declare no conflict of interest.

We thank our nursing stuff and our patients for making this study possible.

\section{References}

1. Storb R, Deeg HJ, Pepe M, Appelbaum F, Anasetti C, Beatty P, Bensinger W, Berenson R, Buckner CD, Clift R. Methotrexate and cyclosporine versus cyclosporine alone for prophylaxis of graft-versus-host disease in patients given HLA-identical marrow grafts for leukemia: long-term follow-up of a controlled trial. Blood. 1989 ;73(6):1729-1734.

2. Ruutu T, van Biezen A, Hertenstein B, Henseler A, Garderet L, Passweg J, Mohty M, Sureda A, Niederwieser D, Gratwohl A, de Witte T. Prophylaxis and treatment of GVHD after allogeneic haematopoietic SCT: a survey of centre strategies by the European Group for Blood and Marrow Transplantation. Bone Marrow Transplant. 2012;47(11):14591464 .

3. Yanada M, Emi N, Naoe T, Sakamaki H, Takahashi S, Hirabayashi N, Hiraoka A, Kanda Y, Tanosaki R, Okamoto S, Iwato K, Atsuta Y, Hamajima N, Tanimoto M, Kato S. Tacrolimus instead of cyclosporine used for prophylaxis against graft-versus-host disease improves outcome after hematopoietic stem cell transplantation from unrelated donors, but not from HLA-identical sibling donors: a nationwide survey conducted in Japan. Bone Marrow Transplant. 2004;34(4):331-337.

4. Kanda Y, Kobayashi T, Mori T et al. A randomized controlled trial of cyclosporine and tacrolimus with strict control of blood concentrations after unrelated bone marrow transplantation. Bone Marrow Transplant. 2016;51(1):103109.

5. Uberti JP, Silver SM, Adams PT, Jacobson P, Scalzo A, Ratanatharathorn V. Tacrolimus and methotrexate for the prophylaxis of acute graft-versus-host disease in allogeneic bone marrow transplantation in patients with hematologic malignancies. Bone Marrow Transplant. 1997;19(12):12331238 .

6. Hiraoka A, Ohashi Y, Okamoto S et al. Phase III study comparing tacrolimus (FK506) with cyclosporine for graftversus-host disease prophylaxis after allogeneic bone marrow transplantation. Bone Marrow Transplant. 2001;28(2):181185.

7. Inamoto Y, Flowers ME, Appelbaum FR et al. A retrospective comparison of tacrolimus versus cyclosporine with methotrexate for immunosuppression after allogeneic hematopoietic cell transplantation with mobilized blood cells. Biol Blood Marrow Transplant. 2011;17(7):1088-1092.

8. Luznik L, Bolaños-Meade J, Zahurak M, Chen AR, Smith BD, Brodsky R et al. High-dose cyclophosphamide as single-agent, short-course prophylaxis of graft-versus-host disease. Blood. 2010;115(16):3224-3230.

9. Kanakry CG, O'Donnell PV, Furlong T, de Lima MJ, Wei W, Medeot M et al. Multi-institutional study of post-transplantation cyclophosphamide as single-agent graft-versushost disease prophylaxis after allogeneic bone marrow transplantation using myeloablative busulfan and fludarabine conditioning. J Clin Oncol. 2014 ;32(31):3497-3505.

10. Kanakry CG, Bolaños-Meade J, Kasamon YL, Zahurak M, Durakovic N, Furlong T et al. Low immunosuppressive burden after HLA-matched related or unrelated BMT using posttransplantation cyclophosphamide. Blood. 2017;129(10):1389-1393.

11. Kanakry CG, Coffey DG, Towlerton AM, Vulic A, Storer $\mathrm{BE}$ et al. Origin and evolution of the $\mathrm{T}$ cell repertoire after posttransplantation cyclophosphamide. JCI Insight. 2016;1(5). pii: e86252. Epub 2016 Apr 21.

12. Przepiorka D, Weisdorf D, Martin P, Klingemann HG, Beatty P, Hows J, Thomas ED. 1994 Consensus Conference on Acute GVHD Grading. Bone Marrow Transplant. 1995; 15:825-828.

13. Filipovich AH, Weisdorf D, Pavletic S, Socie G, Wingard JR, Lee SJ, Martin P, Chien J, Przepiorka D, Couriel D, Cowen EW, Dinndorf P, Farrell A, Hartzman R, Henslee-Downey J, Jacobsohn D, McDonald G, Mittleman B, Rizzo JD, Robinson M, Schubert M, Schultz K, Shulman H, Turner M, Vogelsang G, Flowers ME. National Institutes of Health consensus development project on criteria for clinical trials in chronic graft-versus-host disease: I. Diagnosis and staging working group report. Biol Blood Marrow Transplant. 2005;11:945956.

14. Sorror ML, Maris MB, Storb R, Baron F, Sandmaier BM, Maloney DG, Storer B. Hematopoietic cell transplantation (HCT)-specific comorbidity index: a new tool for risk assessment before allogeneic HCT. Blood. 2005;106(8):2912-2919.

15. Armand P, Kim HT, Logan BR, Wang Z, Alyea EP, Kalaycio ME, Maziarz RT, Antin JH, Soiffer RJ, Weisdorf DJ, Rizzo JD, Horowitz MM, Saber W. Validation and refinement of the Disease Risk Index for allogeneic stem cell transplantation. Blood. 2014;123(23):3664-3671. 
16. Kohl M, Plischke M, Leffondre K, Heinze G. PSHREG: a SAS macro for proportional and nonproportional subdistribution hazards regression. Comput Methods Programs Biomed. 2015;118(2):218-233.

17. Cho BS, Yahng SA, Lee SE, Eom KS, Kim YJ, Kim HJ, Lee S, Min CK, Cho SG, Kim DW, Lee JW, Min WS, Park CW. Validation of recently proposed consensus criteria for thrombotic microangiopathy after allogeneic hematopoietic stem-cell transplantation. Transplantation. 2010;90(8):918926.

18. Jagasia M, Arora M, Flowers ME, Chao NJ, McCarthy PL, Cutler CS et al. Risk factors for acute GVHD and survival after hematopoietic cell transplantation. Blood. 2012;119(1):296-307.

19. Ross D, Jones M, Komanduri K, Levy RB. Antigen and lymphopenia-driven donor $\mathrm{T}$ cells are differentially diminished by post-transplantation administration of cyclophosphamide after hematopoietic cell transplantation. Biol Blood Marrow Transplant. 2013;19(10):1430-1438.

20. Kanakry CG, Bolaños-Meade J, Kasamon YL, Zahurak M, Durakovic N, Furlong T et al. Low immunosuppressive burden after HLA-matched related or unrelated BMT using posttransplantation cyclophosphamide. Blood. 2017;129(10):1389-1393.

21. Calcineurin Inhibitor-Free Interventions for Prevention of Graft-versus-Host Disease (BMT CTN 1301). NCT02345850, Clinicaltrials.gov as of 11/11/2017.

22. Weisdorf D, Zhang MJ, Arora M, Horowitz MM, Rizzo JD, Eapen M. Graft-versus-host disease induced graft-versus-leukemia effect: greater impact on relapse and disease-free survival after reduced intensity conditioning. Biol Blood Marrow Transplant. 2012;18(11):1727-1733.

23. Woo M, Przepiorka D, Ippoliti C, Warkentin D, Khouri I, Fritsche H, Körbling M. Toxicities of tacrolimus and cyclosporin A after allogeneic blood stem cell transplantation. Bone Marrow Transplant. 1997;20(12):1095-1098.

24. Moiseev IS, Pirogova OV, Alyanski AL, Babenko EV, Gindina TL, Darskaya EI, Slesarchuk OA, Bondarenko SN, Afanasyev BV. Graft-versus-host disease prophylaxis in unrelated peripheral blood stem cell transplantation with post-transplantation cyclophosphamide, tacrolimus, and mycophenolate mofetil. Biol Blood Marrow Transplant. 2016;22(6):1037-1042.

25. Carreras E, Diaz-Ricart M. The role of the endothelium in the short-term complications of hematopoietic SCT. Bone Marrow Transplant. 2011;46(12):1495-1502.

26. Bilinski J, Robak K, Peric Z, Marchel H, Karakulska-Prystupiuk E, Halaburda K et al. Impact of Gut Colonization by Antibiotic-Resistant Bacteria on the Outcomes of Allogeneic Hematopoietic Stem Cell Transplantation: A Retrospective, Single-Center Study. Biol Blood Marrow Transplant. 2016;22(6):1087-1093. 


\title{
Сравнение монопрофилактики реакции «трансплан- тат против хозяина» с использованием пост-транс- плантационного циклофосфана и профилактики на основе ингибиторов кальциневрина при аллогенной родственной трансплантации костного мозга
}

\author{
Иван С. Моисеев ${ }^{1,2}$, Ольга В. Пирогова ${ }^{1}$, Елена В. Бабенко ${ }^{1}$, Елена И. Дарская ${ }^{1}$, Елена В. Морозова ${ }^{1,2}$, \\ Сергей Н. Бондаренко ${ }^{1}$, Борис В. Афанасьев ${ }^{1,2}$ \\ ${ }^{1}$ НИИ детской онкологии, гематологии и трансплантологии им. Р. М. Горбачевой \\ ${ }^{2}$ Кафедра гематологии, трансфузиологии и трансплантологии, Первый Санкт-Петербургский государственный \\ медицинский университет имени академика И. П. Павлова, Санкт-Петербург, Россия
}

\section{Резюме}

В настоящий момент опубликован ряд исследований, показавших эффективность профилактики реакции «трансплантат против хозяина» (РТПХ) с использованием пост-трансплантационного циклофосфана в качестве единственного препарата (моноПТЦф) при HLA-совместимых трансплантациях костного мозга (ТКМ). Тем не менее, до сих пор не было опубликовано прямых сравнений эффективности моноПТЦф и классической профилактики с использованием ингибиторов кальциневрина (ИКН). В данном исследовании проведено сравнение результатов ТКМ у 78 пациентов, получавших профилактику РТПХ с использованием моноПТЦф, и 105 пациентов исторического контроля, получавших профилактику такролимусом/циклоспорином А и микофенолатом мофетилом/метотрексатом. Исследуемые группы были сравнимы по клиническим характеристикам, однако в группе с ИКН было больше пациентов группы «спасения» и больший процент пациентов с острым лимфобластным лейкозом. ПТЦф достоверно лучше предотвращал развитие острой РTПX II-IV (HR 0.239, 95\% CI 0.099$0.58, \mathrm{p}=0.002$ ) и III-IV степени (HR 0.192, 95\% CI 0.055-0.666, p=0.009), а также снижал вероятность рецидива (HR 0.519, 95\% CI 0.297-0.893, p=0.023).
Частота хронической РТПХ (HR 0.898, 95\% CI 0.477$1.69, \mathrm{p}=0.74)$ и трансплантационной летальности (HR 0.384, 95\% CI 0.089-1.437, p=0.1768) достоверно не различались между группами. В группе пациентов с моноПТЦф наблюдалась достоверно более высокая общая выживаемость (HR 0.489, 95\% CI 0.261-0.917, p=0.03), бессобытийная выживаемость (HR 0.571, 95\% CI 0.334-0.976, p=0.04) и выживаемость без рецидива и РTПХ (HR 0.493, 95\% CI 0.309-0.786, p=0.003). Токсичность ТКМ была сравнима в двух группах, за исключения меньшей нефротоксичности ( $33 \%$ против $43 \%, \mathrm{p}=0.008)$ и частоты пост-трансплантационной микроангиопатии (3\% против $11 \%, \mathrm{p}=0.04)$ режима с ПТЦф, и большей частотой мукозитов 3-4 степени при данном режиме (41\% против $34 \%, \mathrm{p}=0.02$ ). Несмотря на недостатки ретроспективного и одноцентрового подхода, в данном исследовании было показано преимущество режима профилактики РТПХ на основе моноПТЦф. Полученные результаты должны быть подтверждены в проспективном рандомизированном исследовании.

\section{Ключевые слова}

Трансплантация костного мозга, реакция «трансплантат против хозяина», пост-трансплантационный циклофосфан, профилактика. 